\title{
Thin Layer Drying Characteristics of Sweet Potato Starch Based Films and Mathematical Modelling
}

\author{
Cozy Saini, Sukhcharn Singh and D.C. Saxena*
}

Department of Food Engineering and Technology, Sant Longowal Institute of Engineering and Technology, Longowal, Punjab, India

\begin{abstract}
Drying kinetics of sweet potato starch based films was studied at different temperatures $\left(45,50,55\right.$ and $\left.60^{\circ} \mathrm{C}\right)$. Films were prepared by casting technique and were dried in hot air oven. In declining rate period, moisture transfer from films was described by applying the Page's model, and the rate constant (k) was calculated. Results indicated that removal of moisture from these thin films was fast in initial hours and with increase of temperature as well. The effect of temperature on rate constant $(k)$ was interpreted according to Arrhenius law. The rate constant increased $\left(0.000-0.002 \mathrm{~h}^{-1}\right)$ with the drying air temperature.
\end{abstract}

Keywords: Sweet potato; Films; Drying kinetics; Page's model

Nomenclature: E: Activation Energy $\left(\mathrm{kJ} \mathrm{mol}^{-1}\right)$; $\mathrm{k}$ : Rate Constant $\left(\mathrm{h}^{-1}\right)$; MR: Moisture Ratio (dimensionless); M: Moisture Content at any given Instant (kg water/kg dry solids); $\mathrm{m}_{\mathrm{e}}$ : Equilibrium Moisture Content (kg water $/ \mathrm{kg}$ dry solids); $\mathrm{m}_{\mathrm{o}}$ : Initial Moisture Content $(\mathrm{kg}$ water/kg dry solids); n: Dimensionless Coefficient; R: Universal Gas Constant $\left(8.314 \mathrm{~kJ} \mathrm{~mol}^{-1} \mathrm{~K}^{-1}\right)$; T: Absolute Temperature (K); t: Time of Rehydration or Dehydration (h)

\section{Introduction}

The production of plastics has been increasing considerably due to the extensive growth of world population. Plastics are becoming part and parcel of our day to day life and as a result plastic industry has emerged as a rapidly expanding industry in the past several decades. There is $4 \%$ growth in plastic production annually, creating hundreds of tons of residues daily [1]. Over the past century the topic of "green chemistry" has gained increased attention. In order to solve the problems generated by plastic waste, particularly by disposable commodities, many efforts have been made to develop environment friendly materials $[2,3]$. The treatment of waste plastics has become a serious problem because of the difficulty of ensuring reclaimed land and burning by incineration [4]. The industry is now facing ecological and legislative issues for handling plastic raw materials and finished products [5]. Currently, the most part of raw material used for packaging are from petroleum-based polymers, such as polyethylene and polystyrene. The utilization of biodegradable packaging materials has the greatest potential in countries where landfill is the main waste management tool. Natural bio polymeric films are totally biodegradable and are derived from renewable raw materials and these properties make them advantageous over synthetic polymers. They can be used effectively as an alternative to synthetic plastics. Biopolymers have also desirable overall mechanical and barrier properties [6].

Agriculture-derived biopolymers, such as proteins and polysaccharides, appears as an interesting alternative to synthetic plastics for some applications, especially those with a short life-time, such as food packaging and add values to agricultural products [710]. Starch a renewable source, appears to be the best raw material of biodegradable polymer with low cost [11]. Starch from different sources has been studied as a potential film-forming agent, including that from potato and barley [12], wheat [13], tapioca [14], and rice [13]. Maize starch [13-16] is a low-cost renewable material containing 15-
$30 \%(\mathrm{w} / \mathrm{w})$ amylose and $70-85 \%(\mathrm{w} / \mathrm{w})$ amylopectin [16] and is used in many applications including the food, pharmaceutical and medical industries, both in its native powdered form and in modified forms [13]. Amylose is primarily responsible for the film-forming ability and functional properties of starch-based films due to its recrystallization behavior after processing. Amylose forms strong and flexible films whereas amylopectin produces weak and brittle ones $[17,18]$. The basic process for preparation of films involves evaporation of solvent from polymer solution and thus forming solid coating on substrate. The effect of a specific drying condition depends on various characteristics of the raw material such as the presence of preexisting gel phase or the occurrence of thermal gelation during drying. The drying kinetics of food is a complex phenomenon and requires simple representations to predict the drying behavior and for optimizing the drying parameters $[19,20]$.

Sweet potato (Ipomoea batatas Lam.) is an important source of carbohydrate for the people in Asia. It is rich in B-carotene, fiber and potassium ion etc. and is widely used in ready-to-eat foods. Roots and tuber crops are grown throughout the world in hot and humid regions. Roots and tubers contain $70-80 \%$ water, $16-24 \%$ starch and trace quantities $(<4 \%)$ of proteins and lipids. Sweet potato (Ipomoea batatas $\mathrm{Lam}$ ) is one of the most economically important species of tropical root and tuber crops, which can grow in great abundance on marginal soils [21]. These are rich in starches (58-76\%, on a dry basis) and its starches have properties similar to those of potato starch [22-24].

Different authors [25-27] reported that the film-forming method and drying process conditions influence film performance. Rindlav et al. [28] reported that crystallinity degree of potato starch edible film is dependent on the temperature, the air humidity and the time that elapses during drying from gel to film. The study of drying properties

${ }^{*}$ Corresponding author: D.C. Saxena, Department of Food Engineering and Technology, Sant Longowal Institute of Engineering and Technology, Longowal, Punjab, India, 148106,Ph: +919815608859; E-mail: dcsaxena@yahoo.com

Received June 12, 2012; Accepted July 16, 2012; Published July 20, 2012

Citation: Saini C, Singh S, Saxena DC (2012) Thin Layer Drying Characteristics of Sweet Potato Starch Based Films and Mathematical Modelling. J Food Process Technol 3:168. doi:10.4172/2157-7110.1000168

Copyright: (c) 2012 Saini C, et al. This is an open-access article distributed under the terms of the Creative Commons Attribution License, which permits unrestricted use, distribution, and reproduction in any medium, provided the original author and source are credited. 
of edible film in relation to its kinetics is a subject of greater importance due to the need of a complete characterization of the film to evaluate advantages and disadvantages of its application in relation to food shelf life. The aim of the present study was to assess the effect of different temperatures on the drying rate of thin layer films.

\section{Material and Methods}

\section{Isolation of starch}

Starch was isolated from sweet potato as per the method described by Singh et al. [29]. Sweet potato were washed, peeled and shred. Shreds were put into plain and chemical added water containing various combinations of chemicals $(0.2 \%$ potassium metabisulphite (KMS), combination of $0.5 \%$ citric acid and $0.1 \% \mathrm{KMS}$ and $0.5 \%$ citric acid and $0.2 \% \mathrm{KMS}$ ) to improve the color of starch. The starch precipitate was transferred to trays and dried in an oven at $40^{\circ} \mathrm{C}$ to a moisture content of $8-10 \%$ (wet basis).

\section{Preparation of starch films}

The starch films were prepared according to the method described by [30]. The films were prepared through the casting technique using a film-forming solution containing $5 \%$ of sweet potato starch. Glycerol at concentrations of ( $10 \%$ on dry starch basis) was used as plasticizer. The mixture ( $5 \%$ dry starch $+95 \%$ water $+10 \%$ glycerol on dry starch basis) was heated to $70^{\circ} \mathrm{C}-80^{\circ} \mathrm{C}$ temperature on hot plate and constant stirring was done for 10 minutes by magnetic stirrer. Mixture was cooled and passed through vacuum pump to remove bubbles and poured (hot) about $25 \mathrm{ml}$ homogenously onto the high density poly propylene (HDPP) plastic trays $(9 \times 9 \times 2 \mathrm{~cm})$. The trays containing the film forming solution were then dried in an oven at different temperature $45,50,55$ and $60^{\circ} \mathrm{C}$ till the equilibrium was achieved. The dried films were peeled off the trays and kept in air tight polyethylene bags.

\section{Drying kinetics}

To determine the drying kinetics, sweet potato films were dried on plastic trays in an oven (M/s. Linco, Ambala, India). The drying oven was equipped with an electrical heater, a fan, and temperature indicator. The airflow was uniform. An approximately $25 \mathrm{ml}$ sample tray was uniformly spread on trays. Samples were removed periodically after $10 \mathrm{~min}$ and weighed by an electronic balance up to two decimal places. The films were dried up to the level, until equilibrium moisture content was reached. When drying was completed, the average moisture content of each sample was analyzed according to the hot air oven method. Experiments were performed to determine the effect of process variables on drying kinetics. The variables examined were the temperature $45,50,55$ and $60^{\circ} \mathrm{C}$.

\section{Statistical evaluation}

The series of drying experiments at different conditions such as different temperatures $\left(45,50,55\right.$ and $\left.60^{\circ} \mathrm{C}\right)$ at constant air velocity. The results obtained from correlation and regressions comparing the estimates of random and systematic errors were evaluated based on F-value at a probability level of $5 \%$.

\section{Results and Discussion}

\section{Drying rate}

The typical drying rate curves at different drying temperatures are shown in Figure 1. The variation of moisture content with drying time was obtained at each drying temperature. From these results, drying rates were calculated and plotted against time. The drying rates were computed using a Lagrangian numeric differentiation technique utilizing three data points. It was observed that the drying rate decreased continuously throughout the drying period. The drying of films took place in the falling rate period. Similar types of observations on the thickness reduction of films with respect to temperature have also been studied by other workers [31].

\section{Selection of the drying model}

The convective drying of biological materials in the falling rate period is a diffusion-controlled process and may be represented by Fick's second law of diffusion. Various types of mathematical models have been used to describe drying of foodstuffs, ranging from theoretical models based on classical diffusion theory and simplified forms of these to purely empirical models [32-34]. However, the non-Fickian models have been observed during drying of viscoelastic food materials where both relaxation and diffusion affect mass transfer [35]. One equation that has been used successfully to describe drying behavior is Page's equation as below:

$$
\mathrm{MR}=\left(\mathrm{m}-\mathrm{m}_{\mathrm{e}}\right) /\left(\mathrm{m}_{\mathrm{o}}-\mathrm{m}_{\mathrm{e}}\right)=\exp \left(-\mathrm{kt}^{\mathrm{n}}\right)
$$

The linear form of Eq. (1) is

$$
\operatorname{In}[-\operatorname{In}(\mathrm{MR})]=\operatorname{In}(\mathrm{k})+\mathrm{n} \operatorname{In}(\mathrm{t})
$$

Linear regression of Equation (1) was carried out using the least squares technique and the coefficients were determined. The values of the coefficients are reported in Table 1. As seen in Figure 1-3, Page's equation adequately described the drying of sweet potato starch based films over selected range of drying air temperatures. The coefficient of determination was greater than 0.976 and standard errors were less than 0.053 in all the cases, as shown in Table 1.

\begin{tabular}{|l|l|l|l|l|}
\hline Temp $\left({ }^{\circ} \mathbf{C}\right)$ & $\mathbf{k}$ & $\mathbf{N}$ & $\mathbf{R}^{2}$ & Standard Error \\
\hline $\mathbf{4 5}$ & 0.00098 & 1.574 & 0.988 & 0.035 \\
\hline $\mathbf{5 0}$ & 0.00145 & 1.568 & 0.9768 & 0.053 \\
\hline $\mathbf{5 5}$ & 0.00199 & 1.543 & 0.9892 & 0.04 \\
\hline $\mathbf{6 0}$ & 0.00226 & 1.559 & 0.9854 & 0.051 \\
\hline
\end{tabular}

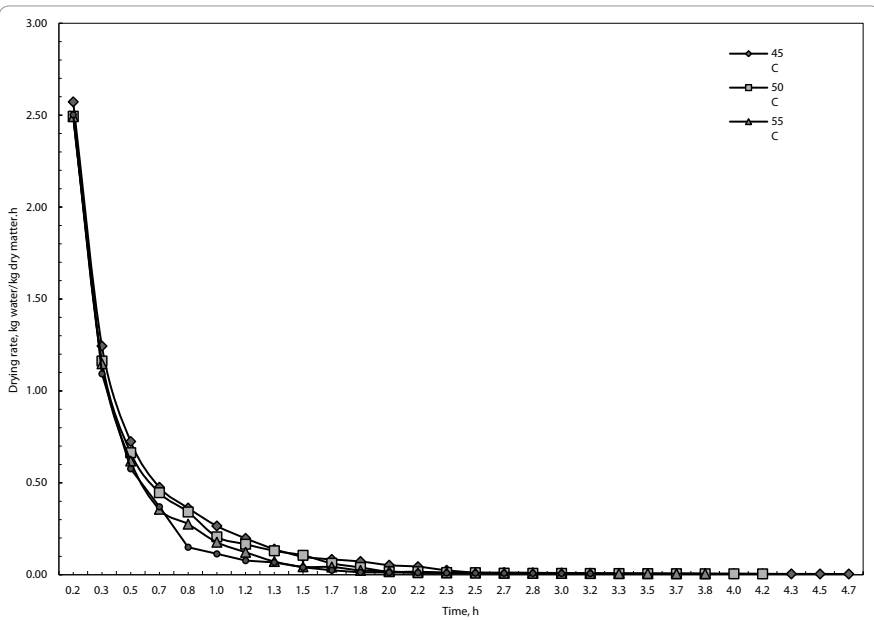

Figure 1: Effect of temperature on drying rate of sweet potato starch based films. 
Citation: Saini C, Singh S, Saxena DC (2012) Thin Layer Drying Characteristics of Sweet Potato Starch Based Films and Mathematical Modelling. J Food Process Technol 3:168. doi:10.4172/2157-7110.1000168

\section{Effect of temperature variables on drying characteristics}

It was observed that the total time of drying reduced significantly with the increase in the temperature of hot air. As the temperature increases the drying reduced. The rate constant $(\mathrm{k})$ increased $(0.000-$ 0.002) with the drying air temperature. The results suggested that the Arrhenius law might be applicable to relate the dependence of the rate constant on drying air temperature. The relationship is given by the following equation:

$$
\mathrm{k}=\mathrm{k}_{\mathrm{o}} \exp (-\mathrm{E} / \mathrm{RT})
$$

The computed values for activation energy for films were $26.89 \mathrm{~kJ}$ $\mathrm{mol}^{-1}$. Plots of $\ln \mathrm{MR}$ against drying time showed a linear relationship (Figure 3) and verify the dependence of drying air temperature.

\section{Conclusion}

Drying took place in the falling rate period, and Page's model was found to describe well the drying behavior of sweet potato starch based films. The drying rate constant was related to temperature using the

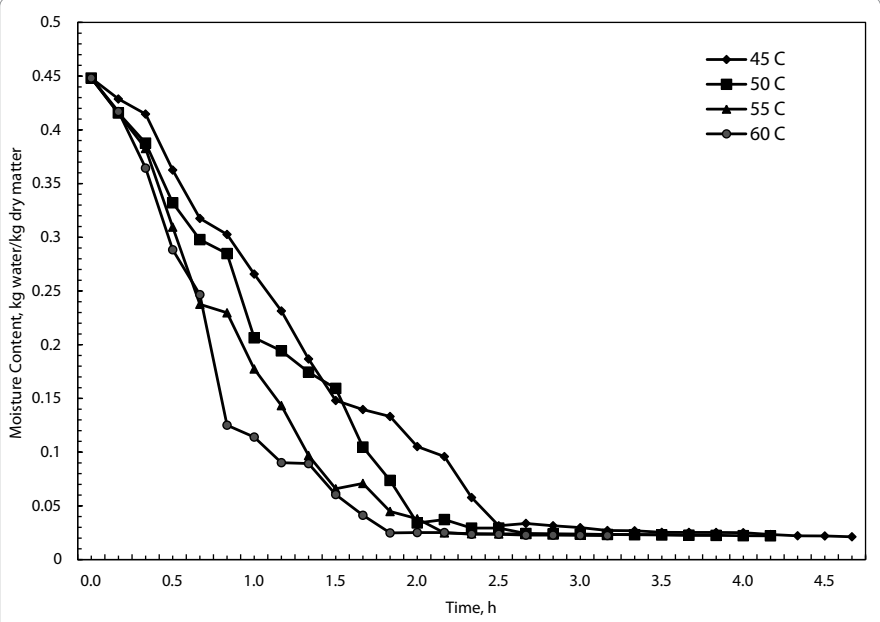

Figure 2: Effect of temperature on moisture content of sweet potato starch based films.

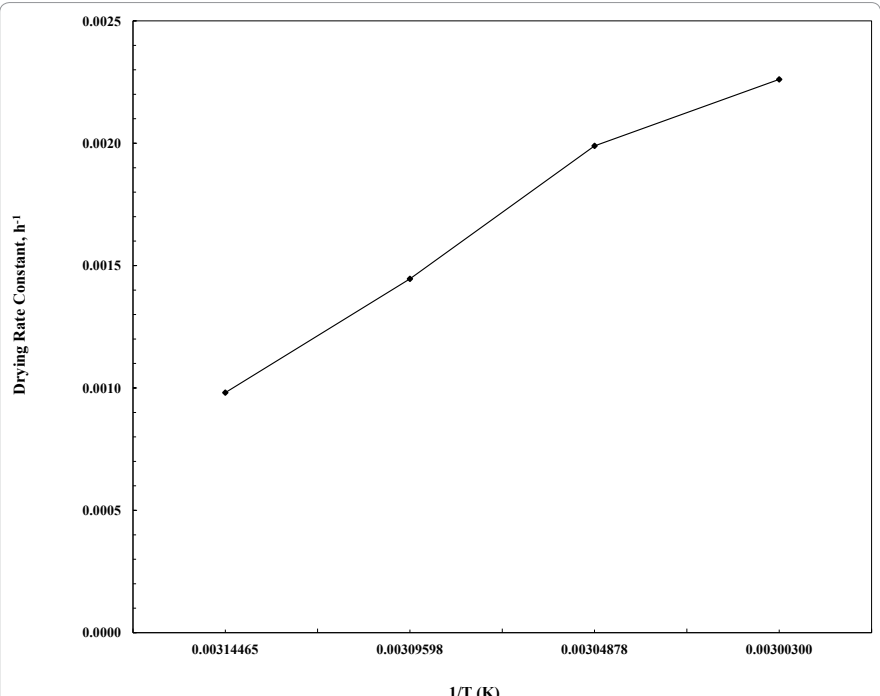

Figure 3: Temperature dependence of drying rate constant of sweet potato starch films.
Arrhenius relationship. It would be possible to attain faster drying with increased drying temperature up to $60^{\circ} \mathrm{C}$ with reduced time. Drying took place entirely in the falling rate period.

\section{References}

1. Arandes JM, Bilbao JD, Lopez Valerio D (2004) Reciclado de residuos plásticos. Revista Iberoamericana de Polímeros 5: 28-45.

2. Scott G (2000) Green polymers. Polym Degrad Stab 68: 1-7.

3. Pandey JK, Singh RP (2005) Green nanocomposites from renewable resources: effect of plasticizer on the structure and material properties of clayfilled starch. Starch-Starke 57: 8-15.

4. Doi Y, Takmaki A, Kunioka M, Soga K (1998) Production of esters of 3-hydroxybutyrate and 3-hydroxyvalerate by Alcaligenes eutrophus from butyric acid and pentanoic acids. Applied Microbiology and Biotechnology 28: 330-334.

5. Mody AS (2000) Biodegradable polymer. Popular Plastics and Packaging 12 89-91.

6. Guilbert S, Gontard N Gorris LGM (1996) Prolongation of shelf-life of perishable food products using biodegradable films and coatings. LWT - Food Science and Technology 29: 10-17.

7. Arvanitoyannis IS (1999) Totally-and-partially biodegradable polymer blends based on natural and synthetic macromolecules: preparation and physical properties and potential as food packaging materials. Journal of Macromolecular Science, Part C: Polymer Reviews 39: 205-271.

8. Ribeiro C, Vicente AA, Teixeira JA, Miranda C (2007) Optimization of edible coating composition to retard strawberry fruit senescence. Postharvest Bio Technol 44: 63-70.

9. Tapia-Blácido D, Mauri AN, Menegalli FC, Sobral PJ, Añón MC (2007) Contribution of the starch, protein, and lipid fractions to the physical, thermal, and structural properties of amaranth (Amaranthus caudatus) flour films. J Food Sci 72: 293-300.

10. Salgado PR, Schmidt VC, Molina Ortiz SE, Mauri AN, Laurindo JB (2008) Biodegradable foams based on cassava starch, sunflower proteins and cellulose fibers obtained by a baking process. J Food Eng 85: 435-443.

11. Lorcks J (1998) Properties and applications of compostable starch-based plastic material. Polym Degrad Stab 59: 245-249.

12. Koskinen MT, Suortti K, Autio P, Myllärinen KP (1996) Effect of pretreatment on the film forming properties of potato and barley starch dispersions. Ind Crops Prod 5: 23-34.

13. Moore CO, Tuschhoff JV, Hastings CW, Schanefelt RV (1984) Applications of starches in foods, in Starch: Chemistry and Technology (Eds. R. L. Whistler, J. N. BeMiller, E. F. Paschall) Academic Press, Orlando, FI.

14. Marques PT, Lima AMF, Bianco G, Laurindo JB, Borsali R, et al. (2006) Thermal properties and stability of cassava starch films cross-linked with tetraethylene glycol diacrylate. Polym Degrad Stab 91: 726-732.

15. Rhim JW, Gennadios A, Weller CL, Cezeirat C, Hanna MA (1998) Soy protein isolate-dialdehyde starch films. Ind Crops Prod 8: 195-203.

16. Le Bail P, Morin FG, Marchessault RH (1999) Characterization of a crosslinked high amylose starch excipient. Int J Biol Macromol 26: 193-200

17. Zobel HF (1988) Molecules to granules: a comprehensive starch review. Starch-Stärke 40: 44-50

18. Myllarinen P, Partanen R, Seppala J, Forssell P (2002) Effect of glycerol on behavior of amylose and amylopectin films. Carbohydr Polym 50: 355-361.

19. Cernîşev S (2010) Effects of conventional and multistage drying processing on non-enzymatic browning in tomato. J Food Eng 96: 114-118.

20. Vadivambal R, Jayson DS (2007) Changes in quality of microwave-treated agricultural products- a review. Biosystems Engineering 98: 1-16.

21. Lebot $V$ (2009) Tropical root and tuber crops: Cassava, sweet potato, yams and aroids. In J. Atherton (Ed.), Crop production science in horticulture series. Wallingford: $\mathrm{CAB}$ International. 
Citation: Saini C, Singh S, Saxena DC (2012) Thin Layer Drying Characteristics of Sweet Potato Starch Based Films and Mathematical Modelling. J Food Process Technol 3:168. doi:10.4172/2157-7110.1000168

Page 4 of 8

22. Chen Z, Schols HA, Voragen AGJ (2003) Physicochemical properties of starches obtained from three varieties of Chinese sweet potatoes. J Food Sci 68: 431-437.

23. Gunaratne A, Corke H (2007) Functional properties of hydroxypropylated, cross-linked, and hydroxypropylated cross-linked tuber and root starches. Cereal Chem 84: 30-37.

24. Hoover R (2001) Composition, molecular structure, and physicochemical properties of tuber and root starches: A review. Carbohydr Polym 45: 253-267.

25. Dawson PL, Hirt DE, Rieck JR, Acton JC, Sotthibandhu A (2003) Nisin release from films is affected by protein type and film-forming method. Food Res Int 36: $959-968$

26. Jangchud A, Chinnan MS (1999) Peanut protein film as affected by drying temperature and $\mathrm{pH}$ of film forming solution. J Food Sci 64: 153-157.

27. Menegalli F, Sobral P, Roques M, Laurent S (1999) Characteristics of gelatin biofilms in relation to drying process conditions near melting. Drying Technology 17: 1697-1706.

28. Rindlava A, Hulleman SHD, Gatenholma P (1997) Formation of starch films with varying crystallinity. Carbohydr Polym 34: 25-30.
29. Singh S, Raina CS, Bawa AS, Saxena DC (2005) Effect of heat-moisture treatment and acid modification on rheological, textural, and differentia scanning calorimetry characteristics of sweet potato starch. J Food Sci 70 e373-e378.

30. Muller MOC, Yamashita F, Laurindo BJ (2008) Evaluation of the effects of glycerol and sorbitol concentration and water activity on the water barrier properties of cassava starch films through a solubility approach. Carbohydr Polym 72: 82-87.

31. Karapantsios TD (2006) Conductive drying kinetics of pregelatinized starch thin films. J Food Eng 76: 477-489.

32. Chirife J, Cachero RA (1970) Through-circulation drying of tapioca root. J Food Sci 35: 364-368.

33. Sharaf-Eldeen YI, Hamdy MY, Blaisdell JL (1979) Falling rate drying of fully exposed biological materials. A Review of Mathematical Models ASAE 79: 6522.

34. Karanthanos VT (1999) Determination of water content of dried fruits by drying kinetics. J Food Eng 39: 337-344.

35. Willis B, Okas MR (2001) Mass transfer model for amorphous shrinking food materials. IFT annual meeting, New Orleans, Louisiana, June 23-27. 